DOI: $10.31073 / \mathrm{mivg} 201801-111$

Available (PDF): http://mivg.iwpim.com.ua/index.php/mivg/article/view/111

УДК 532.5:519.86:556.182:556.3:631.621

\title{
РОЗРАХУНКИ ТА ПРОГНОЗУВАННЯ ВПЛИВУ КАР'СРУ "ХОТИСЛАВСЬКИЙ" НА ГІДРОДИНАМІКУ ГРУНТОВИХ І ПІДЗЕМНИХ ВОД ВОЛИНСЬКОГО ПОЛІССЯ
}

\author{
О.О. Дятел ${ }^{1}$, С.В. Телима², канд. техн. наук \\ ${ }^{1}$ Інститут водних проблем і меліорації НАAН, Київ, Україна; е-mail: alexandr_dyatel@ukr.net \\ ${ }^{2}$ Інститут гідромеханіки НАНУ, Київ, Україна; е-mail: office $@$ hydromech.com.ua
}

\begin{abstract}
Анотація. Розглянуто питания впливу розробки кар 'єру «Хотиславський» на гідродинаміку грунтових і підземних вод Волинського Полісся. Використано аналітичні методи розрахунку прочесів геофільтрачії та методи математичного моделювання. Проаналізовано обтрунтованість прогнозних розрахунків та моделювання впливу кар'єру на територію Украйни, виконаних попередніми дослідниками та співставлення даних.

Ключові слова: область фільтрачії, інфільтрачійне живлення, водопритік, водопровідність, гідрогеологічні умови, переосушення, техногенні умови
\end{abstract}

Постановка питання. Розробка кар'єру «Хотиславський» на території Республіки Білорусь упродовж багатьох років є предметом дискусій щодо його можливого впливу на прилеглу територію України.

Актуальність досліджень підтверджена численними науковими висновками відомих фахівців щодо можливого негативного впливу розробки кар'єру на територію Волинського Полісся, включаючи територію Шацького національного парку

Враховуючи вищезазначене, нами було поставлено завдання кількісної оцінки транскордонного впливу на територію України розробки даного родовища на довгостроковий період його експлуатації.

Аналіз останніх досліджень і публікацій. У процесі досліджень були проаналізовані гідрогеологічні умови території Волинського Полісся, визначені умови формування водних ресурсів зони активного водообміну, гідрологічні умови, стан поверхневих водотоків, включаючи меліоративні об'єкти, та сучасний водно-екологічний стан визначеної території.

Крім того, на основі аналізу гідродинамічних умов основних водоносних горизонтів розроблені фільтраційні схеми взаємозв'язку грунтових і підземних вод на даній території, що дозволило створити концептуальну модель водообміну поверхневих і підземних вод.

При створенні моделі були використані та проаналізовані результати моделювання оцінки впливу на оточуюче середовище розробки родовиша «Хотиславське», які представлені у відповідному Звіті білоруської сторони [13] та монографіях $[2,14]$. Показано, що результати впливу слід вважати наближеними у зв'язку з недостатньою достовірністю геофільтраційних даних, які використовувались білоруськими фахівцями.

Метою досліджень $€$ оцінювання впливу розробки родовища піску і крейди «Хотиславське» (Республіка Білорусь) на гідрогеологічні та гідроекологічні умови території України в межах Волинського Полісся, включаючи територію Шацького національного парку.

У роботі використано аналітичні методи розрахунку процесів геофільтрації та методи математичного моделювання. Крім того проведений аналіз обгрунтованості прогнозних розрахунків та моделювання впливу кар'єру на територію України, виконаних білоруською стороною, та співставлення даних.

Результати досліджень. Територія досліджень характеризується складними гідрогеологічними умовами і недостатньо вивчена, особливо це стосується північно-західної частини, де розташована Копаївська осушувальна система $[14,2]$.

Відсутність достовірних даних по окремих ділянках території визначає наближений характер розрахунків та прогнозування впливу експлуатації кар'єру на гідродинаміку грунтових і підземних вод Волинського Полісся в межах його можливого впливу (рис. 1), що відмічено і у Звіті білоруської сторони [13].

Водопритік до кар'єру формується за рахунок природних ресурсів основних водоносних горизонтів та атмосферних опадів і при гідродинамічній схематизації його можна розглядати як радіальний потік до свердло- 


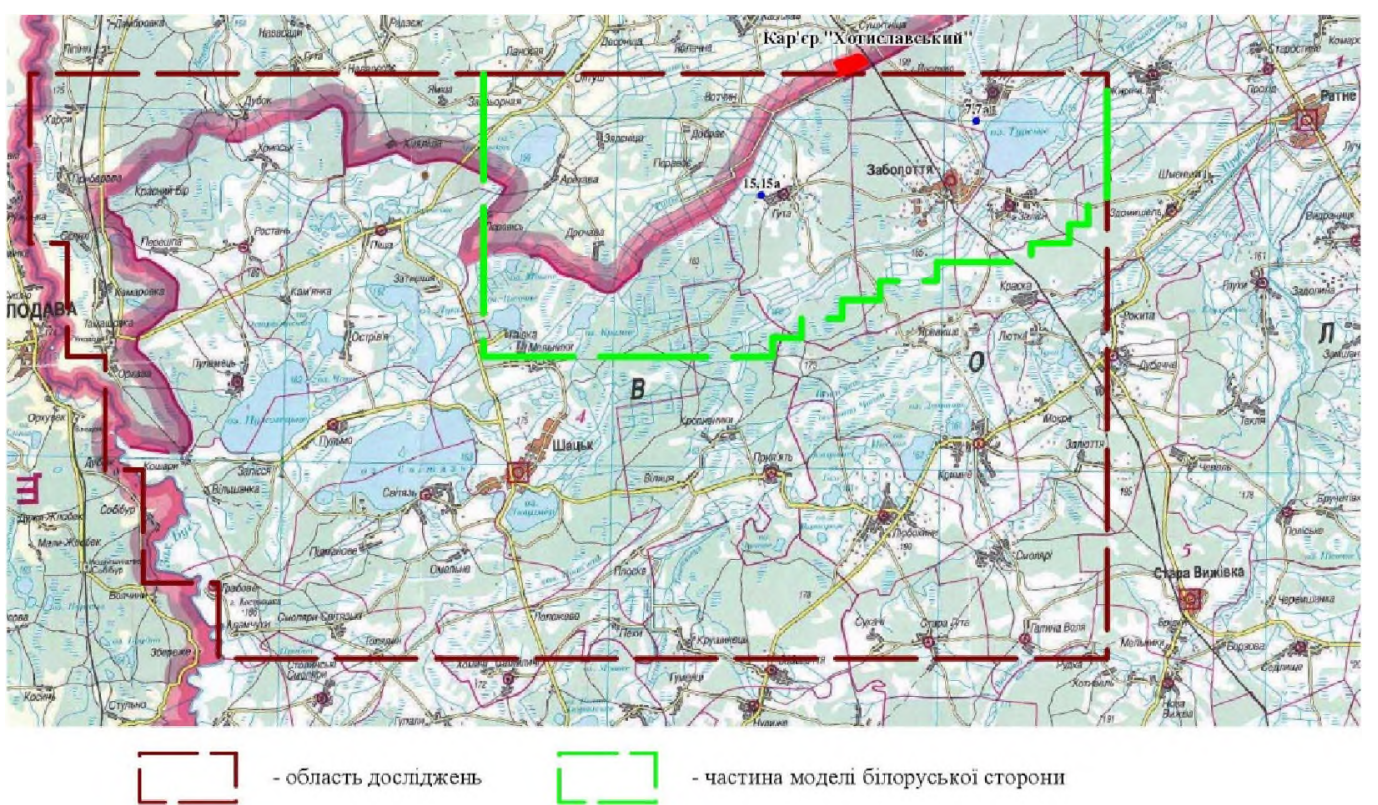

Рис. 1. Оглядова карта району досліджень. Масштаб 1:200 000

вини великого діаметра в необмеженій області фільтрації із заданням на контурі кар'єру відповідних граничних умов (величини водопритоку або постійного зниження на контурі кар'єру).

Виходячи із вищезазначеного, можна розглядати задачу водопритоку до свердловини великого діаметра в тришаровій водоносній товщі, необмеженій в плані, з відсутністю перетікання знизу та з інфільтраційним живленням $[6,12]$.

У припущенні жорсткого режиму фільтрації в слабопроникному розподільному прошарку зони кольматації мергельно-крейдової товщі і неврахуванні інфільтраційного живлення грунтового потоку процес неусталеної фільтрації можна описати системою диференційних рівнянь у часткових похідних [12]:

$$
\begin{array}{r}
a_{1}\left(\frac{\partial^{2} S_{1}}{\partial r^{2}}+\frac{1}{r} \cdot \frac{\partial S_{1}}{\partial r}\right)-b_{1}\left(S_{1}-S_{2}\right)=\frac{\partial S_{1}}{\partial t} \\
a_{1}\left(\frac{\partial^{2} S_{2}}{\partial r^{2}}+\frac{1}{r} \cdot \frac{\partial S_{2}}{\partial r}\right)+b_{1}\left(S_{1}-S_{2}\right)=\frac{\partial S_{2}}{\partial t}
\end{array}
$$

де $a_{1}=T_{1} / \mu_{1}, \quad a_{2}=T_{3} / \mu_{2}, \quad b_{1}=K_{2} / \mu_{1} m_{2}$, $b_{2}=K_{2} / \mu_{2} m_{2} ; S_{1}(r, t)=H_{o i}-H_{i}(r, t)$ - зниження рівнів і напорів у водоносних горизонтах 3 водопровідностями $T_{1}=k_{1} m_{1}$, $T_{3}=k_{3} m_{3} ; H_{o i}$ і $H i(r, t)-$ рівні і напори до початку і в процесі водовідбору $(i=1,2) ; \mu_{1}$ i $\mu_{2}$ - коефіцієнти водовіддачі горизонтів.

Система рівнянь (1) розв'язується при таких граничних умовах:

$$
\begin{gathered}
t=0, \quad S_{1}=S_{2}=0 \\
t>0, r \rightarrow 0,2 \pi T_{1} \frac{\partial S_{1}}{\partial r} \rightarrow-Q, \frac{\partial S_{2}}{\partial r}=0 \\
t>0, r \rightarrow \infty, S_{1} \rightarrow 0, S_{2} \rightarrow 0
\end{gathered}
$$

де $t$-час, доба; $r$-координати по простору i $Q$ - постійний водовідбір із свердловини.

У роботі [12] наведено загальний аналітичний розв'язок даної задачі за допомогою інтегральних перетворень, який має такий вигляд відносно знижень $S_{1}(r, t)$ і $S_{2}(r, t)$ :

$$
S_{i}(r, t)=\int_{0}^{\infty} p j_{0}(p r) S_{i} \cdot(p, t) d t
$$

Рівняння (3) становить собою складний аналітичний вираз, який можна реалізувати лише чисельним способом. Для цього був розроблений відповідний пакет програм i розраховані спеціальні таблиці фільтраційних опорів для багатошарових схем фільтрації, що значно спрощує розрахунки і моделювання вказаного класу задач $[7,12]$.

Відомо, що в практичних розрахунках процес взаємозв'язку водоносних горизонтів через слабопроникні прошарки при водовідборі з одного із горизонтів, можна розділити на декілька етапів, а саме $[6,7,12]$ :

малі часи, коли величина зниження в суміжному горизонті незначна, а в основному горизонті, 3 якого відбувається водовідбір, можна розглядати фільтрацію по схемі ізольованого пласта; проміжні часи, коли починається перетікання із суміжного горизонту; 
проміжні великі часи, коли відбувається нерівномірне зниження рівнів і напорів в обох горизонтах; час, коли величину зниження можна розраховувати по схемі одношарового пласта 3 інтегральними параметрами усієї водовміщуючої товщі:

$$
S_{1}(r, t)=S_{2}(r, t)=\frac{Q}{4 \pi T} w(u)
$$

де $\quad T=T_{1}+T_{3}, \quad \mu=\mu_{1}+\mu_{2}, \quad a=T / \mu$, $w(u)$ - функція Тейса, $u=r^{2} / 4 a t$.

Для малих часів вираз для розрахунку часового критерію роботи свердловини по схемі одношарового пласта має вигляд [7]:

$$
t_{1} \leq 0,01 \mu_{1} m_{2} / K_{2}
$$

Підставляючи у вираз дані по водоносному горизонту четвертинних відкладів в районі кар' сру $\mu_{1}=0,2, m_{2}=10,0 \mathrm{M}, K_{2}=5 \cdot 10^{-3} \mathrm{M} /$ добу, отримуємо, що $\mathrm{t}_{1} \leq 4$ доби, тобто водовідбір 3 кар'єру за рахунок лише горизонту грунтових вод відбувався протягом 4 діб, після чого почалась взаємодія 3 нижнім горизонтом у мергельно-крейдовій товщі через перетікання знизу-вверх.

Оскільки, згідно 3 проектними рішеннями [13], видобуток крейди та піску 3 кар'єру планується до 2040 р., тобто на 30 років, починаючи 32009 р., коли відбулось освоєння першої черги родовища, то представляє інтерес розрахунку часового критерію, після якого відбір 3 кар'єру можна змоделювати по схемі одношарового пласта 3 інтегральними параметрами усієї водоносної товщі. Для даного випадку рекомендується залежність [7]:

$$
t_{1} \geq 20 B^{2} / a_{2}, \quad r / B \geq 5
$$

де $B$ - параметр перетікання, м; $a_{2}-$ коефіцієнт п'єзопровідності, м²/добу.

Підставляючи дані по ділянці кар'єру, взяті 3 моделі білоруської сторони, отримуємо що $B=419$ м. При $\mathrm{a}_{2}=1,3 \cdot 10^{4} \mathrm{м}^{2} /$ добу, $\mathrm{t}_{2} \geq 270$ діб, тобто через 270 діб систему водоносних горизонтів можна розглядати як єдиний водоносний горизонт з інтегральними параметрами усієї водовміщуючої товщі.

Як правило, при розрахунках кар'єрного водовідливу оперують поняттями відпрацювання глибини кар'єру із відповідними зниженнями рівнів грунтових вод у ньому. Прогнозування відносно знижень $є$ більш обгрунтованим порівняно із заданням на кар'єрі проектних значень водовідливу, оскільки при розробці родовищ визначення величин водовідливу є наближеним у більшій мірі порівняно із розрахунками розповсю- дження воронок депресії при постійному зниженні по контуру кар' єру.

Враховуючи прийняту схематизацію гідрогеологічних умов у розрізі по території досліджень, для визначення впливу розробки кар'єру на рівневий режим підземних вод була використана залежність $[1,9]$ :

$$
S(r, t)=S_{0} \cdot A(\tau, \rho)
$$

де $S(r, t)$ - величина зниження на момент часу $\mathrm{t}$ на відстані $\mathbf{r}$ від кар'єру; $r_{0}$ - радіус «великого колодязя», тобто кар'єру, м; $S_{0}-$ проектна величина зниження рівня грунтових вод при водовідливі, м; $A(\tau, \rho)$ - спеціальна табульована функція; $\tau=a t / r_{0}^{2} ; \rho=r / r_{0}$.

Перевага застосування даної моделі полягає в тому, що підрахунок знижень береться від існуючих рівнів грунтових вод, у яких у неявній формі враховується інфільтраційне живлення і для довгострокових прогнозів таке припущення є обгрунтованим [9].

Оскільки в результатах моделювання білоруської сторони фігурує величина проектного зниження 12,0 м при розробці першої черги родовища, було виконано моделювання розповсюдження змін у рівнях грунтових вод на проектний період, починаючи 3 початку освоєння (2009 р.) до 2040 року при $S_{0}=12,0$, на основі залежності виду (7).

Дані чисельного моделювання при різних відстанях від кар'єру при $S_{0}=12,0$ м наведені в таблиці 1.

За результатами моделювання побудовано графік знижень рівня грунтових вод у залежності від відстані від кар'єру по площі можливого впливу на 2025 рік (рис. 2).

Як видно з табл. 1 та графіку знижень, станом на 2025 р. можливий вплив досягне річки Прип'ять, де прогнозується Зниження $S=0,115$ м. Радіус впливу складатиме більш як 16 км. У зону впливу потраплять озера Святе, Велихово, водосховище Турське та значна кількість населених пунктів прикордонної з Білоруссю території.

Рівні води в озерах Святе та Велихово знизяться відповідно на 2,02 і 1,62 м при існуючій глибині оз. Святе 15,0 м, тобто глибина озера може зменшитися близько 2 м. Що стосується водосховища Турського, то при його глибині 2,0 м зниження на 1,35 м практично змінить його гідрологічний режим $[14,5]$. Крім того, зниження рівнів грунтових вод у зоні впливу на 0,5-1,5 м погіршить умови водозабезпечення проживаючого в цій зоні населення.

Для порівняння 3 прогнозними рішеннями білоруської сторони на 2040 р. при $S_{0}=12,0$ м 
1. Величини знижень рівнів грунтових вод на ділянці досліджень за результатами чисельного моделювання при $S_{0}=12,0$ м

\begin{tabular}{|c|c|c|c|}
\hline № & Відстань від кар'єру, & \multicolumn{2}{|c|}{$S_{0}=12,0 \mathrm{~m}$} \\
\cline { 3 - 4 } п/н & км & $2016-2025 \mathrm{pp}, \mathrm{t}=10$ років & $2016-2040 \mathrm{pp}, \mathrm{t}=25$ років \\
\hline 1. & оз. Святе, 6,0 & $2,02 \mathrm{M}$ & $3,08 \mathrm{M}$ \\
2. & с. Гута, 7,0 & $1,62 \mathrm{M}$ & $2,6 \mathrm{M}$ \\
3. & смт. Заболоття,7,0 & $1,62 \mathrm{M}$ & $2,6 \mathrm{M}$ \\
4. & оз. Волихове, 7,2 & $1,48 \mathrm{M}$ & $2,55 \mathrm{M}$ \\
5. & вдсх. Турське, 7,6 & $1,35 \mathrm{M}$ & $2,38 \mathrm{M}$ \\
6. & с. Заліси, 10,0 & $0,73 \mathrm{M}$ & $0,99 \mathrm{M}$ \\
7. & с. Яревище, 14,4 & $0,23 \mathrm{M}$ & $0,85 \mathrm{M}$ \\
8. & р. Прип'ять, 16,4 & $0,115 \mathrm{M}$ & $0,60 \mathrm{M}$ \\
9. & оз. Кримно, 17,2 & - & $0,5 \mathrm{M}$ \\
10. & смт. Ратне, 23,4 & - & $0,17 \mathrm{~m}$ \\
11. & оз. Люцимер, 25,6 & - & $0,1 \mathrm{M}$ \\
\hline
\end{tabular}

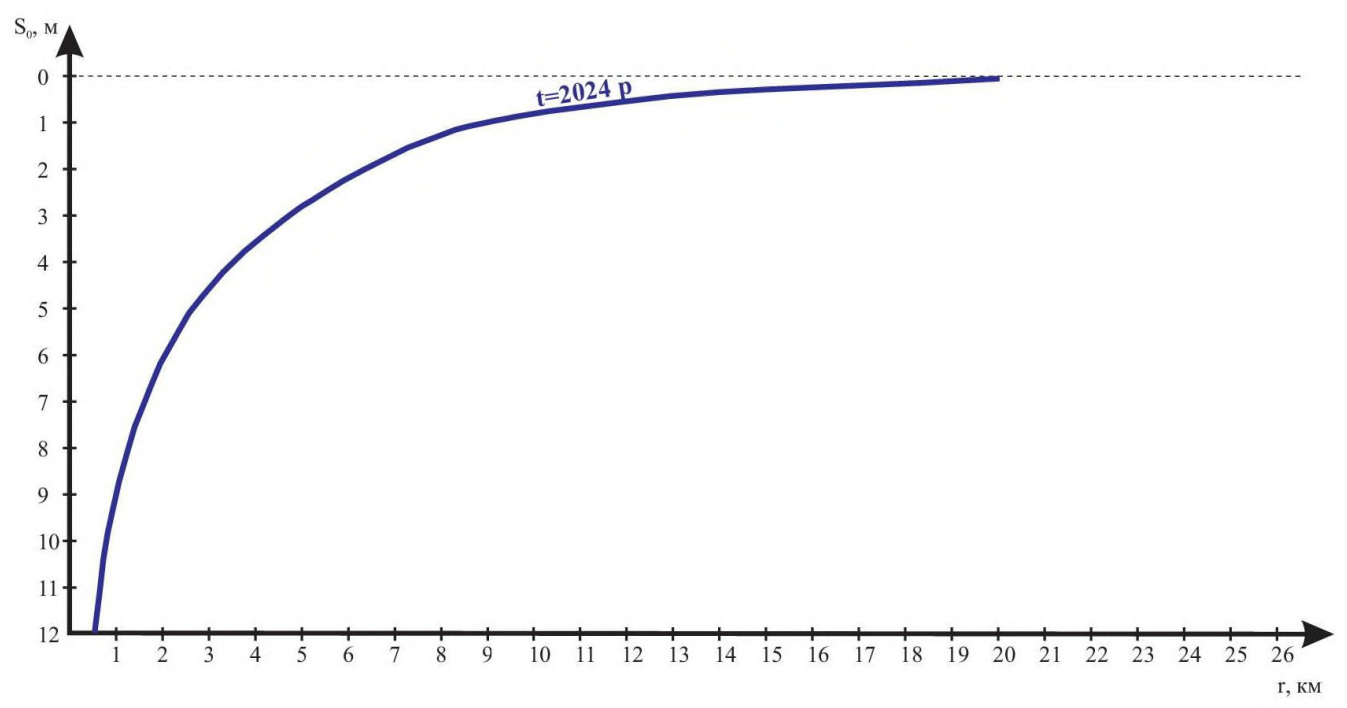

Рис. 2. Графік залежності величини зниження рівня грунтових вод від відстані до кар'єру при зниженні на його контурі $S_{0}=12,0$ м на 2025 рік відпрацювання кар'сру

побудована відповідно схематична карта розповсюдження впливу розробки кар'єру на рівневий режим грунтових вод у масштабі 1:200 000 (рис. 3). Як видно 3 карти, величини знижень суттєво відрізняються між собою, а розповсюдження зони впливу за даними моделювання білоруської сторони станом на 2040 р. в деякій мірі співпадає 3 даними проведених розрахунків при $S_{0}=12,0$ м станом на 2025 p. із

врахуванням і без врахування компенсаційних заходів щодо зменшення зони впливу на територію України. Отже, навіть при розробці лише верхньої частини розрізу кар'єру прогнозований вплив охопить значну територію України.

Нами проведено розрахунки знижень рівнів грунтових вод на прилеглій до кар'єру території на кінець 2009, 2013, 2015 і 2016 років згідно даних білоруської сторони про водовідлив 3 кар'єру на основі залежності (4) Так, на 2009 р. при $Q=1500 \mathrm{~m}^{3} /$ добу зниження на контурі кар'єру становило близько 1,8 м, а біля водосховища Турське (спостережні свердловини 7 і 7а (рис. 1) вплив не спостерігається, $S<0,1 \mathrm{м}$ ); станом на 2013 р. при $Q=1200 \mathrm{~m}^{3} /$ добу зниження на контурі кар'єру становило порядку 1,95 м, а в районі спостережних свердловин 7 i 7a - порядку 0,1 м; станом на 2015 р. при $Q=7176 \mathrm{~m}^{3} /$ добу величина зниження досягла 12,4 м, а біля водосховища Турське - 1,2 м; станом на 2016 р. при $Q=8354,7 \mathrm{~m}^{3} /$ добу величина зниження розраховується $S=14,8 \mathrm{~m}$, а в районі водосховища Турське - біля $1,4 \mathrm{~m}$.

Аналогічні розрахунки проведені на відстані 7,0 км (с. Гута), де розташовані спостережні свердловини 15 i 15 a (рис. 1). 


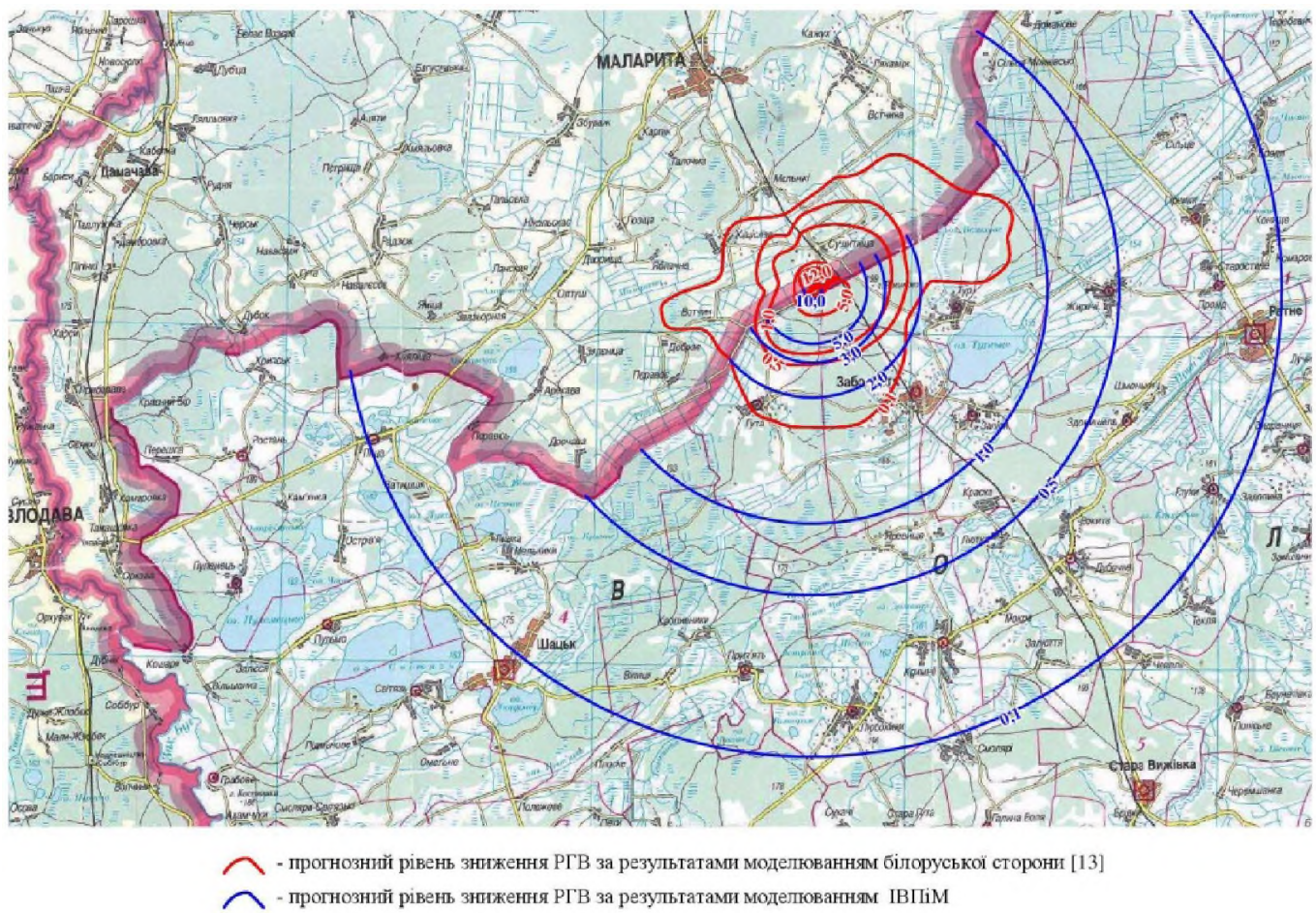

Рис. 3. Карто-схема прогнозних знижень рівнів грунтових вод на площі області досліджень на 2040 р. при зниженні на контурі кар'єру $S_{0}=12,0$ м

Аналіз даних розрахунків і даних спостережних свердловин свідчить про те, що має місце достатне узгодження даних розрахунків 3 режимними спостереженнями, оскільки i режимні дані і розрахункові дані показують майже однакові зниження рівнів грунтових вод на відстані 7,0-7,6 км від кар'єру станом на 2016 p.

Порівняльна характеристика отриманих даних дозволяє стверджувати, що для схематизованих техногенних умов в зоні можливого впливу експлуатації кар'єру вказані розрахункові моделі обгрунтовано відображають процес змін водообміну на прилеглих до кар'єру територіях.

Аналогічну картину слід чекати стосовно річкової мережі. Враховуючи той факт, що майже всі водотоки на території характеризуються незначними глибинами, наприклад глибина р. Прип'ять біля с. Річиця становить 2,73 м, а вище по руслу ще менша, глибина р. Вижівка біля смт. Вижівка $-0,97$ м, то не виключено, що буде можливе пересихання усіх річок. Поступово замість функції дренування річкова система перетвориться на область живлення грунтових вод, зниження рівня яких обумовить збільшення потужності зони аерації і осушення водоносного горизонту.

Слід відмітити, що на прогнозований період зросте також і водовідбір із водонос- ного комплексу для водозабезпечення населення питною водою. Усього планується збільшення водовідбору до 50 тис. м²/добу і в цілому із врахуванням водовідливу 3 кар'єру водовідбір зросте до 70-75 тис. м³/добу [13].

Отже, проведені чисельно-аналітичні розрахунки та моделювання показали, що розробка родовища піску i крейди «Хотиславське» на запроектований період експлуатації до 2040 p. суттєво змінить гідродинамічні умови території Волинського Полісся і в цілому погіршить гідрогеологоекологічну ситуацію на визначеній території.

Висновок. За результатами чисельного моделювання для I черги, $S_{0}=12,0$ м, витікає, що станом на 2025 р. можливий вплив досягне річки Прип'ять, де прогнозується зниження $S=0,115$ м. Радіус впливу складатиме більше 16 км. У зону впливу потраплять озера Святе, Велихово, водосховище Турське та значна кількість населених пунктів прикордонної 3 Білоруссю територіі, що спричинить погіршення умов водозабезпечення.

Порівняльна характеристика отриманих даних дозволяє стверджувати, що для схематизованих антропогенних умов в зоні можливого впливу експлуатації кар'єру, вказані розрахункові моделі обгрунтовано відображають процес змін водообміну на прилеглих до кар'єру територіях. 


\section{Бібліографія}

1. Основы гидрогеологических расчетов. Бочевер Ф. М. и др. Москва: Недра, 1965. 250 с.

2. Шацьке поозер'я. Геологічна будова та гідрогеологічні умови. Залеський I.I. та ін. Луиьк: Східноєвропейський національний університет, 2014. 188 с.

3. Заявление о воздействии на окружающую среду планируемой хозяйственной деятельности «Разработка меловой залежи месторождения «Хотиславское» (II очередь) в Малоритском районе Брестской области». Минск: Кварителпром, РУП ЦЦНИИКИВР, ГНПО «НАН Беларуси по биоресурсам», 2009. 12 c.

4. Зузук Ф. В. Вірогідність впливу розробки Хотиславського родовища крейди на заповідні екосистеми Волині. // Зб. наук. праць "Природа Західного Полісся", Луиьк: СНУ ім. Лесі Украӥнки. 2016. 스9. С. 3-11.

5. Ільїн Л. В. Озера Волині: лімногеографічна характеристика. Луцьк: Надстир'я, 2000. 140 с.

6. Ломакин Е. А., Мироненко В. А., Шестаков В. М. Численное моделирование геофильтрачии. Москва: Недра, 1988. 228 с.

7. Методические рекомендачии по расчетам зачиты территорий от подтопления в зоне оромения. Киев: Минводхоз УССР, 1986. 392 с.

8. Мокрий B. I. Моніторинг, моделювання і прогнозування впливу Хотиславського кар'сру на гідрогеологічні і лісоекологічні умови природно-заповідних об'сктів Західного Полісся. "/ Зб. наук. прачь "Природа Західного Полісся та прилеглих територій", Луцьк: СНУ ім. Лесі Украйнки. 2012. №9. С. 284-288.

9. Норватов Ю.А. Изучение и прогноз техногенного режима подземных вод. Ленинград: Недра, 1988. 261c.

10.0 мониторинге в районе месторождения "Хотиславское". Письмо Минприроды Республики Беларусь Министерству экологии и природных ресурсов Украины от 24.07.2017 за №3-10/36-имо. Минск, 2017. 12 c.

11. О мониторинге в районе месторождения песка и мела "Хотиславское". Письмо Министерства природных ресурсов и охраны окруљсающей среды Республики Белорусь. Минск: №13-11/3536-вн om 27.12.2016.11 c.

12. Олейник А. Я. Фильтрачионные расчеты вертикального дренажа. Киев: Наукова думка, 1978. $202 \mathrm{c}$.

13. Отчет о результатах проведения оценки воздействия на окружающую среду добычи мела на участке месторождения «Хотиславское» в Малоритском районе Брестской области. В 2-x книгах. Кн. 1. Оченка воздействия разработки месторождения мела «Хотиславское» (ІІочередь) нагидролого-гидрогеологические условия прилегающей территории. Министерство природных ресурсов и охраны окружающей среды Республики Белорусь. Республиканское унитарное предприятие «Центральный научно-исследовательский институт комплексного использования водных ресурсов (РУП «ЦНИИКИВР»). Минск, 2009. 142 c.

14.Природа Західного Полісся, прилеглого до Хотиславського кар'єру Білорусі / за ред. Ф.В. Зузука. Лучьк: Східноєвропейський національний університет, 2014. 246 c.

15. Ромащенко М. І., Бахмачук Ю. Й. Формування режиму природних вод району Шаиьких озер в сучасних умовах. Київ: Аграрна наука, 2004. 96 с

16.Водообмен в гидрогеологических структурах Украины. Методы изучения водообмена. Шестопалов В. М. и др. Киев: Наукова думка, 1988. 267 с.

\section{References}

1. Bochever, F., Garmonov, I., Lebedev, D., Shestakov, V. (1965). Osnovy gidrogeologicheskikh raschetov [Foundations of hydrogeological calculations]. Moscow: Nedra. [in Ukrainian].

2. Zaleskiy, I., Zuzuk, F., Melnychuk, V., Matejuk, V. (2014). Shats'ke poozer'ya. Heolohichna budova ta hidroheolohichni umovy [Shatskoe lake. Geological structure and hydrogeological conditions]. Lutsk: Skhidnoyevropeys'kyy natsional'nyy universytet. [in Ukrainian].

3. Kvartsmelprom, RUP TSNIIKIVR, GNPO «NAN Belarusi po bioresursam» (2009). Zayavleniye o vozdeystvii na okruzhayushchuyu sredu planiruyemoy khozyaystvennoy deyatel'nosti "Razrabotka melovoy zalezhi mestorozhdeniya "Khotislavskoye» (II ochered') v Maloritskom rayone Brestskoy oblasti» [Statement on the impact on the environment of the planned economic activity "Development of a chalk deposit "Hotislavskoe "(Phase II) in the Malorita District of the Brest Region"]. Bilorus', Minsk. [in Russian].

4. Zuzuk, F. (2016). Virohidnist' vplyvu rozrobky Khotyslavs'koho rodovyshcha kreydy na zapovidni ekosystemy Volyni [Probability of the influence of the development of the Khotilaslovskoe field of chalk on the protected ecosystems of Volyn]. Pryroda Zakhidnoho Polissya. Lutsk, SNU im. Lesi Ukrayinky. 9. P. 3-II. 
5. Ilyin, L. (2000). Ozera Volyni: limnoheohrafichna kharakterystyka [Lakes of Volyn: Limogeographical characteristic]. Lutsk: Nadstyr'ya. [in Ukrainian].

6. Lomakin, E., Mironenko, V., Shestakov, V. (1988). Chislennoye modelirovaniye geofil'tratsii [Numerical modeling of geofiltration]. Moscow: Nedra. [in Russian].

7. Metodicheskiye rekomendatsii po raschetam zashchity territoriy ot podtopleniya $v$ zone orosheniya [Methodical recommendations for calculating the protection of territories from flooding in the irrigation zone]. (1986). Kiev: Minvodxoz USSR. [in Russian].

8. Mokryy, V.I. (2012). Monitorynh, modelyuvannya i prohnozuvannya vplyvu Khotyslavs'koho kar'yeru na hidroheolohichni $i$ lisoekolohichni umovy pryrodno-zapovidnykh ob'yektiv Zakhidnoho Polissya [Monitoring, modeling and forecasting of the influence of Khotilaslav's career on hydro-geological and forest-ecological conditions of nature reserves of Western Polissya]. Pryroda Zakhidnoho Polissya ta prylehlykh terytoriy. Lutsk, SNU im. Lesi Ukrayinky, 9. 284-288. [in Ukrainian].

9. Norvatov, Yu. (1988). Izucheniye i prognoz tekhnogennogo rezhima podzemnykh vod [The study and forecast of the technogenic regime of groundwater]. Leningrad: Nedra. [in Russian].

I0.O monitoringe $v$ rayone mestorozhdeniya "Khotislavskoye" [On monitoring in the area of the deposit "Hotislavskoe"]. (2017). Pis'mo Minprirody Respubliki Belarus' Ministerstvu ekologii i prirodnykh resursov Ukrainy ot 24.07.2017 za №3-10/36 - imo. Minsk. [in Russian].

11. O monitoringe v rayone mestorozhdeniya peska i mela "Khotislavskoye" [About monitoring in the area of sand and chalk deposit "Hotislavskoe"] (2016). Pis'mo Ministerstva prirodnykh resursov i okhrany okruzhayushchey sredy Respubliki Belorus'. Minsk: № 13-11/3536-vn 27.12.2016. Minsk. [in Russian].

12.Oleinik, A. (1978). Fil'tratsionnyye raschety vertikal'nogo drenazha [Filtration calculations of vertical drainage]. Kiev: Naukova dumka. [in Russian].

13.RUP «TsNIIKIVR» (2009). Otchet o rezul'tatakh provedeniya otsenki vozdeystviya na okruzhayushchuyu sredu dobychi mela na uchastke mestorozhdeniya "Khotislavskoye" v Maloritskom rayone Brestskoy oblasti. V 2-kh knigakh. Kn. l. Otsenka vozdeystviya razrabotki mestorozhdeniya mela "Khotislavskoye» (II ochered') na gidrologo-gidrogeologicheskiye usloviya prilegayushchey territorii. Ministerstvo prirodnykh resursov i okhrany okruzhayushchey sredy Respubliki Belorus' [Report on the results of the environmental impact assessment of chalk production at the site of the Hotislavskoye deposit in the Malorita district of the Brest Region. In 2 books. Book. 1. Assessment of the impact of the development of the Chotislavskoye chalk deposit (Stage II) on the hydrological and hydrogeological conditions of the adjacent territory. Ministry of Natural Resources and Environmental Protection of the Republic of Belarus]. Minsk. RUP «TsNiIKIIVR». [in Russian].

14.Zuzuk, V.F. (Ed.). (2014) Pryroda Zakhidnoho Polissya, prylehloho do Khotyslavs'koho kar'yeru Bilorusi [Nature of Western Polissya adjacent to Khotyslavsky's career in Belarus]. Lutsk: Skhidnoyevropeys'kyy natsional'nyy universytet. [in Ukrainian].

15.Romashchenko, M. I., Bakhmachuk, YU. Y. (2004). Formuvannya rezhymu pryrodnykh vod rayonu Shats'kykh ozer v suchasnykh umovakh [Formation of the natural waters regime in the Shatsk lakes district in modern conditions]. Kyiv: Ahrarna nauka. [in Ukrainian].

16. Shestopalov, V., Sitnikov, A., Lyalko, V., Pashkovskiy, I. (1988). Vodoobmenv gidrogeologicheskikh strukturakh Ukrainy. Metody izucheniya vodoobmena [Water exchange in hydrogeological structures of Ukraine. Methods of studying water exchange]. Kiev: Naukova dumka. [in Ukrainian].

\section{Расчеты и прогнозирование влияния карьера «Хотиславский» на гидродинамику грунтовых и подземных вод Волынского Полесья}

Рассмотрены вопросы влияния карьера «Хотиславский» на гидродинамику грунтовых и подземных вод Волынского Полесья. Использованы аналитические методы расчета прочессов геофильтрации и методы математического моделирования. Проведен анализ обоснованности прогнозных расчетов и моделирования воздействия карьера на территорию Украины, выполненных предыдущими исследователями, и сопоставление данных.

Calculations and prognosis of the influence of the "Hotyslavsky"

A. Diatel, S. Telyma open cast on the hydrodinamic of the ground and underground waters of the Volyn Polissya The problems of the influence of the "Khotislavsky" quarry on the hydrodynamics of ground and underground waters of Volyn Polissya are considered. At this the analytical methods of calculation of geophiltration processes and methods of mathematical modeling were used. The analysis of the validity of forecast calculations and modeling of the influence of a quarry on the territory of Ukraine carried out performed by previous researchers and the comparison of data are carried out. 